(C) 1988 ISIJ

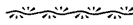

解 説

1"
表示材料の最近の開発状況

馬 場 宣 良*

\title{
Topics and Recent Progress in Display Materials
}

Nobuyoshi BABA

\section{1.はじめに}

コンピューターや OA 機器の発展に伴いマンーマシ ンーインターフェイスとしての表示部分はますます重要 な地位を占めるに至つてきた。それは現在の電子機器が IC の高度な集積化と低価格化によつて年ごとに小さく なる，いわゆる軽薄短小なる言葉が世の中に流布するよ うになつたのに比べ，表示部分だけは軽薄ではあつても 短小であつてはならず，かえつて大面積で高密度，高品 質の表示が求められているからである。このような観点 から最近の表示部分の開発の動きを概説してみることに する。

図 1 はマン-マシンーインターフェイスとしての表示 素子の役割を図示したものである.コンピューターなど の機械の中から出力される電気信号はディスプレイから 視覚を通してパターン認識され, 次いで頭脳の中で高度 な情報処理がなされ，判断されて次の行動を起こすべく 指示が与えられることを示しているものである.

\section{2. 表示材料の分類}

表示素子を大きく分けるとみずから発光する，つまり 暗いところでも見ることのできる能動素子 (Active type）と, 自らは発光しない暗いところでは見えない受 動素子（Passive type）とに分けて考えることができる.

能動素子の代表は現在広く使われている CRT のこと で，テレビはもちろんのことほとんど $80 \%$ 以上の OA 機器はこの CRT を表示部分に使つている. CRT は現 在大量生産で作られているので，そのコストは限界に近 いまで低下されており，工業的にはほとんど完成された 技術となつている。これにはフォトマイクロファブリ ケーションの技術，印刷技術，各種の蒸着，めつき，ス パッタリング，エッチング技術などの粋を集めたもので

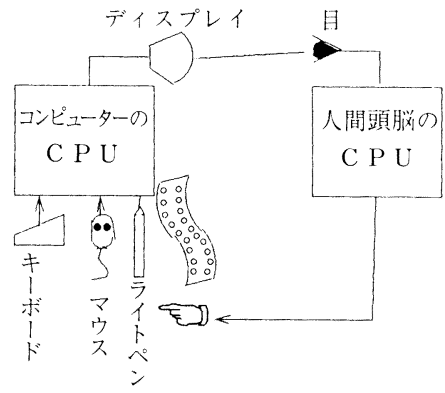

図 1 マンーマシンーインターフェイスとしてのディ スプレイ

ある。

CRT の歴史はほとんど半世紀にわたる研究の成果で あり，長い歴史を持つているので一朝一夕に完成された ものではない.

しかし，これから述べるフラットタイプの表示素子は 最近開発研究が本格的に始められたものが大部分であ り，その歴史は長いものでも十数年である．CRT は総 合的には確かにすぐれたものではあるが，表示面が湾曲 していて画面の端の方は歪みが出ることは避けられな い。また CRT は電子線を発射し，さらに加速する必要 があるためにある一定の距離＝厚さがどうしても必要に なつてくる．そこでこれに必要な高電圧を発生するため に電源関係が大きくなり，重量もかなりになつてくるこ とは周知のとおりである（図 2).

これを改善すべくいろいろなタイプのフラットパネル が研究されている. 薄型で大面積のフラットパネルは近 い将来壁掛けテレビとして一般家庭にも入り込んでいく ことであろう。

昭和 63 年 2 月 7 日受付 (Received Feb. 7,1988)（依頼解説）

* 東京都立大学工学部教授 工博 (Faculty of Technology, Tokyo Metropolitan University, 2-1-1 Fukasawa Setagaya-ku, Tokyo 158)

Key words : CRT display ; pattern recognition ; EL display ; liquid crystal display ; luminescence ; functional material ; light emitting diode ; plasma display ; EC display ; electrophoresis. 


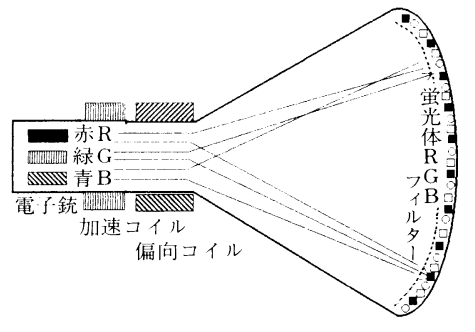

図 2 カラー CRT の構造

\section{3. 発光型表示材料}

$3 \cdot 1$ エレクトロルミネッセンス (ELD) $)^{1 \sim 31}$

発光型の表示材料として理想的なものはこの ELDで ある. EL の原理は蛍光体の両端に高い電場を印加する と, 加速された電子のエネルギーによつて蛍光体が発光 することを応用した表示材料である。この素子がもつ他 に追随を許さない特徵は素子全体が薄型でしかも全固体 型であることである，その他の素子，例えばいま CRT に次いで広く用いられている液晶表示素子にはその名の とおり液体部分を含んでいる．また CRT は大きな真空 の空間をもちかさばつている. 現在電子機器部品の多く のものが究極的には全固体型を目指しており，例えば昔 非常に大きい空間を占めていた真空管は，今では全固体 の小さなシリコントランジスターに置き代わり，電解液 を含んだアルミニウム電解コンデンサーは，小さな全固 体型のタンタルコンデンサーになるといつたたぐいであ る。また，電池にしても液体を含む乾電池からこれまた 全固体型のよう化銀電池にとつて代わろうとしている. こうした動きの中で表示素子もまた全固体型が理想とな るのは当然のことといわねばならない.

ELD にはもう一つ他に追随を許さない特徵がある。 それは発光面のバックに無反射の黒い面を用いることが できて，これにより直射日光下でも表示が見えるという ことで，これは自動車や列車などの計器盤としてすぐれ た特徴となつている．ELD は全固体型であるから振動 に強く, 気圧の急激な变化に対しても安定であるなど航 空機の計器盤としても信頼性が高い.

EL 素子にはその構造から次の二つに分類できる（図 $3)$.

$3 \cdot 1 \cdot 1$ 分散型 $\mathrm{EL}$

これは絶縁物の中に蛍光体の粉末を分散させて，その 絶縁物の両端に高い電場を印加する構造をもつている. 絶縁物の薄膜に有機物薄膜を用いることもできて，これ はフレキシブルな EL 薄膜となる．膜面全体が発光す るので面発光源としてインテリアなどの用途が考えられ たことがあつた．現在ではディスプレイとしての直接的 な用途よりも液晶表示素子などの受光型の表示素子の

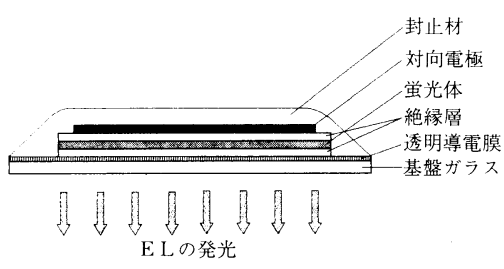

溥膜型E L ( T F E L ) の構造

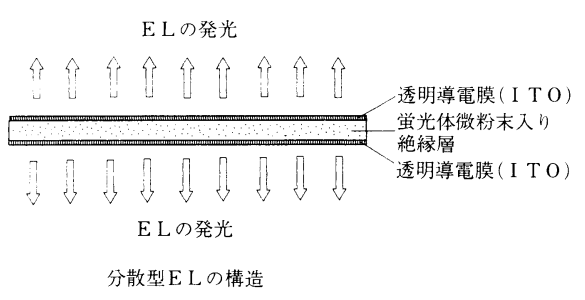

図 3 薄膜型および分散型 EL の構造

バックライトとしての用途の方がもつとも有望である. 発光の効率は次に述べる薄膜型に比べると低い.

\section{$3 \cdot 1 \cdot 2$ 薄膜型 $\mathrm{EL}$}

これは 2 枚の絶縁物の間に蛍光体層を挟み，その両端 に高い電場を印加するような構造になつている. 発光の 効率が分散型のものに比べると高く，高い輝度のものが 得られている. 現在表示素子として試みられているもの はこの薄膜型 EL でこれを以後 TFEL と略称する.

一方印加する電場のかけ方から分類すると

$\mathrm{A}$ : 直流駆動型と B : 交流駆動型の二つのタイプに分類 することができる. 従つて全部で 4 通りの EL 素子が あるわけである.

直流型と交流型とを比べてみると，一般に交流型の方 が高い輝度が得られるので発光効率はこれら四つの夕イ プの中では最も高い. 直流型では電流が一方向にのみ流 れるので，水分などの侵入があると電気分解現象などが 起こりやすく, 寿命が短いのが久点である. これを改善 するために電流制御層として $\mathrm{ZnSe}, n-\mathrm{Si}, \mathrm{MnO}_{x}, \mathrm{Cu}$ コートの $\mathrm{ZnS}$ 等の抵抗層を挿入する試みもなされてい る.このタイプの素子は直流駆動のため低電圧での駆動 が可能であり，すでに $24 \mathrm{~V} て ゙$ 約 $400 \mathrm{~cd} / \mathrm{m}^{2}$, 発光効率 $0.1 \mathrm{~lm} / \mathrm{W}$ のものが得られている．高橋らが開発した MBE 法による EL 薄膜もまた直流駆動型である。これ は $\mathrm{GaAs}$ 単結晶の上に $\mathrm{MBE}$ 法を使つて $\mathrm{ZnSe}$ 系の蛍 光体を成長させたものと報告されており，10 V 以下の 電圧で発光するなど注目を集めた.

交流による駆動方法の場合には印加電圧はかなり高く 100 ボルトを超える.ELにおける最大の研究課題は印 加電压を低くすることに尽きるだろう．現在，EL 発光 素子には赤色発光に Eu を用いた蛍光体が開発され，緑 
色発光には $\mathrm{Tb}$ をドープした蛍光体が高い輝度を示して 実用段階に入つている。フルカラー表示にするためには 3 原色が必要である. カラーテレビの 3 原色では RGB (Red, Green, Blue) が使われているから，もう…つ Blue すなわち青色発光の蛍光体が必要となる. 現在の ところ青色発光の蛍光体に発光効辩が良いものがない. 青色発光は波長が最も短い可視領域であり,この発光を 可能にする蛍光体母体のバンドギャップは大きいものの 方が有利である。それには現在の硫化垔鉛系の蛍光体母 体に代わつて, 硫化カルシウムあるいは硫化ストロンチ ウム系の母体が有望であると最近考えられるようになつ てきた. 特に硫化ストロンチウムは $\mathrm{Sr}^{2+}$ のイオン半径 がドープされる希土類元素のイオン半径に近いため格子 の置換が起こりやすい利点をもつている.

表 1 に現在知られている EL 用の蛍光体の種類とそ の発光色の一覧を示す。これを $x$ - $y$ 色度四に表示する

表 $1 \mathrm{EL}$ の種類と蛍光体 (発光材料) および発光 色 ${ }^{1)}$

\begin{tabular}{|c|c|c|}
\hline ELの種類 & 発 光 材 料 & 発光色 \\
\hline 分散型交流 EL & $\begin{array}{l}\mathrm{ZnS}: \mathrm{Cu}, \mathrm{X} \\
\mathrm{ZnS}: \mathrm{Cu}, \mathrm{Mn}, \mathrm{X} \\
\mathrm{ZnS}: \mathrm{Ag}, \mathrm{Cu}, \mathrm{X} \\
\end{array}$ & $\begin{array}{l}\text { 青-緑 } \\
\text { 黄橙色 } \\
\text { 急 } \\
\end{array}$ \\
\hline 分散型直流 EL & $\begin{array}{l}\mathrm{ZnS}: \mathrm{Cu}, \mathrm{Mn}, \mathrm{X} \\
\mathrm{CaS}: \mathrm{Ce}=\mathrm{Mn} \\
\mathrm{Ba}_{2} \mathrm{ZnS}_{3}: \mathrm{Mn}\end{array}$ & $\begin{array}{l}\text { 黄橙色 } \\
\text { 線 色 } \\
\end{array}$ \\
\hline 薄膜型交流 EL & $\begin{array}{l}\mathrm{ZnS}: \mathrm{Mn} \\
\mathrm{ZnS}: \mathrm{Sm}, \mathrm{F} \\
\mathrm{ZnS}: \mathrm{Eu}, \mathrm{F} \\
\mathrm{ZnS}: \mathrm{Tb}, \mathrm{F} \\
\mathrm{ZnS}: \mathrm{Tm}, \mathrm{F} \\
\mathrm{CaS}: \mathrm{Eu} \\
\mathrm{CaS}: \mathrm{Ce} \\
\mathrm{SrS}: \mathrm{Ce}\end{array}$ & 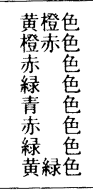 \\
\hline 溥膜型直流 EL & $\begin{array}{l}\mathrm{Au} / \mathrm{ZnSe}: \mathrm{Mn} / \mathrm{GaAs} \\
\mathrm{ITO} / \mathrm{ZnS}: \mathrm{Mn} / \mathrm{ZnSe} / \mathrm{Al} \\
\mathrm{ITO} / \mathrm{ZnSe} / \mathrm{ZnS}: \mathrm{Tb}, \mathrm{F} / \mathrm{Al} \\
\text { ITO } / \mathrm{ZnS}: \mathrm{Mn} / \mathrm{p}-\mathrm{nSi} \\
\mathrm{Cd}_{2} \mathrm{SnO}_{4} / \mathrm{ZnS}: \mathrm{Mn} / \mathrm{a}-\mathrm{Si}: \mathrm{H} / \mathrm{Al}\end{array}$ & $\begin{array}{l}\text { 黄橙色 } \\
\text { 黄橙色 } \\
\text { 緑色 } \\
\text { 黄橙色 } \\
\text { 黄橙色 }\end{array}$ \\
\hline
\end{tabular}

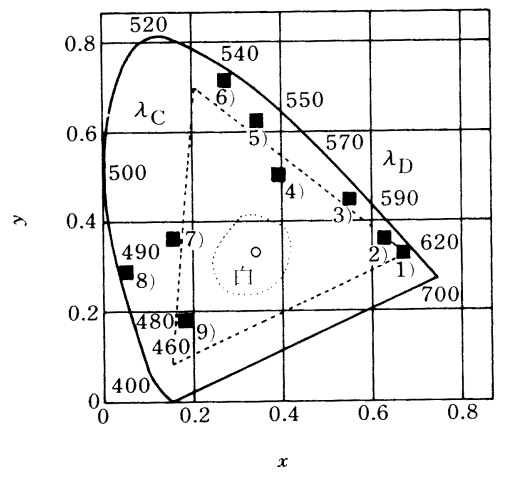

1) $\mathrm{CaS}: \mathrm{Eu}$ 2) $\mathrm{ZnS}: \mathrm{Sm}$ 3) $\mathrm{ZnS}: \mathrm{Mn}$

4) $\mathrm{ZnS}: \mathrm{Pr}$ 5) $\mathrm{ZnS}: \mathrm{Tb}$ 6) $\mathrm{ZnS}: \mathrm{Tb}$

7) $\mathrm{SrS}: \mathrm{Ce}$ 8) $\mathrm{ZnS}: \mathrm{Tb}$ 9) $\mathrm{ZnS}: \mathrm{Tm}$

図 4 各種薄膜 EL デバイスの色度座標
と闵4のようになる。ここで白で囲まれた範井は視覚的 には色がない領域であり，点線の三角形の頂点は理想的 な $\mathrm{R}$ (赤) $\mathrm{G}$ (緑) $\mathrm{B}$ (青) の座標点である. 実際に得 られている蛍光体は 1 から 9 までの四角点で表される. 赤の頂点には非常に近いところに CaS : Eu 蛍光体があ るが, 緑と青の頂点には近いところに適当な蛍光体はな く，やや離れて存在する。自然の色に忠実にするために はこの RGB 色度図上の調節のほかに，各三原色の強度 を同じにすることが重要で,これは発光強度あるいは発 光効率に深く関係する．また表 2 には薄膜型の EL に 用いられる絶緣層材料をまとめたＥLの寿命は誘電体 の絶緣破壊と膜の剝離が原因で決まる、絶緣破壊は高い 電場勾配のもとで電子衝撃が次々と増幅されながら伀わ つていく、いわゆる電子なだれ現象によつて起こる，誘 電体の持つ性質として一度絶緣破壊が起こつてもその場 所だけが局部的に蒸発飛散し，その影響が洁りに波及し ない夕イプのものを自己回復型（SB）とよぶ. …j . . 度絶緣破壊が起こるとその破壊が周りに次々と伝播する タイプのものを破壊伝播型（PB）とよぶ. ELの誘電 体としては SB 型の方が望ましい。ここで膜の剥離の 一番の原因は水分の侵入であるといわれている. 水分は イオン電流を増やし, 電気分解現象によつてガス発生や ふくれが生じ，膜の剥離になるものである．ガラス基板 からのアルカリイオンの溶出があるとイオン電流の増加 につながる．水分の侵入を防ぐにはデバイス全体を緻密 に封じることが第一で，それに使われる封止材の性能が 成否の鍵を握つている.

表 3 には現在実用化されている ELDの発光色とその

表 2 薄膜型 EL に用いられる絶䋑層材料 ${ }^{2)}$

\begin{tabular}{|c|c|c|c|c|c|}
\hline 材 料 & 成膜法 & 比誘電染 & 絶縁眯压 & $Q_{\max }$ & 破壊モード \\
\hline $\begin{array}{l}\mathrm{Y}_{2} \mathrm{O}_{3} \\
\mathrm{Sm}_{2} \mathrm{O}_{3} \\
\mathrm{Al}_{2} \mathrm{O}_{3}\end{array}$ & $\begin{array}{l}\mathrm{EB} \\
\mathrm{EB} \\
\mathrm{EB}, \mathrm{SP}\end{array}$ & $\begin{array}{l}11-12 \\
15-16 \\
6-10\end{array}$ & $\begin{array}{l}3-5 \mathrm{MV} / \mathrm{cm} \\
2-4 \\
5\end{array}$ & $\begin{array}{l}3-5 \mu \mathrm{C} / \mathrm{cm}^{2} \\
3-6 \\
4\end{array}$ & $\begin{array}{l}\text { SB } \\
\text { SB } \\
\text { SB }\end{array}$ \\
\hline $\begin{array}{l}\mathrm{SiO}_{2} \\
\mathrm{Si}_{3} \mathrm{~N}_{4}\end{array}$ & & & & $\begin{array}{l}2 \\
4-6\end{array}$ & $\begin{array}{l}\mathrm{SB} \\
\mathrm{SB} / \mathrm{PB}\end{array}$ \\
\hline $\begin{array}{l}\mathrm{Ta}_{2} \mathrm{O}_{5} \\
\mathrm{SiAlON} \mathrm{AlON} \\
\mathrm{PbTiO}_{3} \\
\mathrm{BaTiO}_{3} \\
\mathrm{BaTa}_{2} \mathrm{O}_{6} \\
\mathrm{PbNb}_{2} \mathrm{O}_{6} \\
\mathrm{SrTiO}_{3}\end{array}$ & $\begin{array}{l}\text { PCVD } \\
\text { SP } \\
\text { SP } \\
\text { SP } \\
\text { SP } \\
\text { SP } \\
\text { SP } \\
\text { SP }\end{array}$ & $\begin{array}{l}22-25 \\
6 \\
100-150 \\
14-55 \\
22 \\
41 \\
140\end{array}$ & $\begin{array}{l}2-5 \\
8-9 \\
0.5 \\
2-3 \\
3.5 \\
1.5 \\
1.5-2\end{array}$ & $\begin{array}{l}4-11 \\
5-6 \\
7 \\
2-4 \\
7 \\
6 \\
19-25\end{array}$ & \begin{tabular}{|l}
$\mathrm{SB} / \mathrm{PB}$ \\
$\mathrm{SB}$ \\
$\mathrm{PB}$ \\
$\mathrm{PB}$ \\
$\mathrm{SB}$ \\
$\mathrm{SB}$ \\
$\mathrm{PB}$
\end{tabular} \\
\hline
\end{tabular}

表 3 薄膜型交流 EL 素子の輝度と発光効率 ${ }^{1)}$

\begin{tabular}{|c|c|c|c|}
\hline EL 材料 & 発光色 & 輝度 $\left(\mathrm{cd} / \mathrm{m}^{2}\right)$ & 効率 $(\operatorname{lm} / \mathrm{W})$ \\
\hline $\begin{array}{l}\mathrm{ZnS}: \mathrm{Mn} \\
\mathrm{ZnS}: \mathrm{Sm}, \mathrm{F} \\
\mathrm{CaS}: \mathrm{Eu} \\
\mathrm{ZnS}: \mathrm{Tb}, \mathrm{F} \\
\mathrm{CaS}: \mathrm{Ce} \\
\mathrm{ZnS}: \mathrm{Tm}, \mathrm{F} \\
\mathrm{SrS}: \mathrm{Ce}\end{array}$ & $\begin{array}{l}\text { 黄橙色 } \\
\text { 橙丞色 } \\
\text { 変 } \\
\text { 緑 色 } \\
\text { 緑 色 } \\
\text { 青緑色 }\end{array}$ & $\begin{array}{l}5000-10000 \\
600 \\
100 \\
5000 \\
650 \\
5 \\
520\end{array}$ & $\begin{array}{l}1-5 \\
0.05 \\
0.05 \\
1.0-1.5 \\
0.11 \\
0.15\end{array}$ \\
\hline
\end{tabular}


表 4 大型薄膜 $\mathrm{EL}$ パネルの開発状況 ${ }^{2)}$

\begin{tabular}{l|c|c|c|c}
\hline \multicolumn{1}{c}{ 開発機関 } & $\begin{array}{c}\text { 表小面積 } \\
\left(\mathrm{mm}^{2}\right)\end{array}$ & $\begin{array}{c}\text { 画素密度 } \\
(\text { 本 } / \mathrm{mm})\end{array}$ & $\begin{array}{c}\text { 電極数 } \\
(\text { 本 })\end{array}$ & $\begin{array}{c}\text { 画素数 } \\
\text { (方面素) }\end{array}$ \\
\hline シャーフ & $120 \times 192$ & 3.3 & $400 \times 640$ & 25.6 \\
松下電器産業 & $51 \times 218$ & 5.0 & $256 \times 1088$ & 27.9 \\
GTE & $254 \times 320$ & 2.0 & $512 \times 640$ & 32.8 \\
Planar & $152 \times 244$ & 2.6 & $400 \times 640$ & 25.6 \\
Lohja & $98 \times 195$ & 2.6 & $256 \times 512$ & 13.1 \\
NTT & $244 \times 244$ & 0.8 & $192 \times 192$ & 3.7 \\
NTT & $162 \times 246$ & 4.2 & $704 \times 1024$ & 72.1 \\
\hline
\end{tabular}

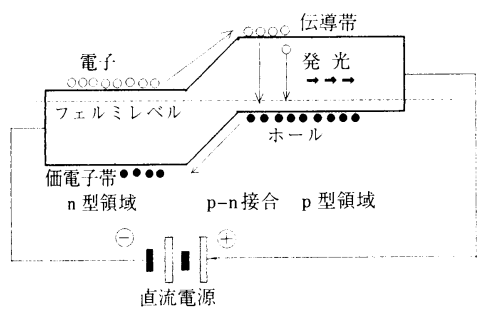

四 5 発光ダイオードの発光機構

輝度および発光効率をまとめて示す．マンガンを付活剤 とした蛍光体がとびぬけて高い効率を示している．EL の発光の特色は固体の発光であるからスペクトルの半值 幅は広く, やわらかい感じの発光色である。また，表 4 には現在開発され，あるいは実用化されている ELDの 諸元を示してある. 画素の数はどこのメーカーもほぼ同 じであるが，これらの中で NTT だけは非常に大きいパ ネルを目指して試作研究をしていることが分かる.

$3 \cdot 2$ 発光ダイオード (LED) $)^{4}$

発光ダイオードは $\mathrm{GaAs} や \mathrm{GaP}$ などの化合物半導体 の pn 接合に順方向バイアスを印加し, 発生した電子正 孔の対が再結合するときに光を放出する現象を利用する

(図 5 ). 化合物半導体のバンドギャップは成分元素の 組成をいろいろ変化させたり，第 3 成分をドープしたり して発光の色を変えることができる.この場合も赤色発 光が最も容易で, 青色発光が一番難しい.

発光ダイオードの作成はその pn 結合を作る技術上あ まり大きいものは作りにくいので，大型のフラットパネ ルを目指すには本質的に不向きであろう，LEDは駆動 電压が数ボルトと低く，また発光効率が比較的高いので フラットパネルディスプレイに使うとすればポータブル なポケットパソコン（ラップトップパソコン）のような ものになるであろう。表 5 には LED の材料組成と発光 色をまとめて示してある.

\section{$3 \cdot 3$ プラズマディスプレイ $(\mathrm{PIP})^{51 \sim 71}$}

プラズマディスプレイは隇压された小さな空間に電压 を印加すると空間に存在するガスがプラズマとなりいわ ゆるプラズマ放電による発光を示す．EL が全固体型の 発光素子であるのに比べて，この PDPは本質的に気体 による発光である，従つて発光の色は残留気体の種類に
表 5 各種 LED の発光色 ${ }^{4)}$

\begin{tabular}{|c|c|c|c|c|}
\hline \multirow{2}{*}{ LED } & \multicolumn{3}{|c|}{ 発 光 特 性 } & \multirow{2}{*}{$\begin{array}{c}\text { 発光効率 } \\
\left(\begin{array}{l}\text { 最値 }) \\
(\operatorname{lm} / \mathrm{W})\end{array}\right.\end{array}$} \\
\hline & 色 & 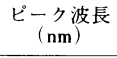 & $\begin{array}{l}\text { 視感度 } \\
(\mathrm{lm} / \mathrm{W})\end{array}$ & \\
\hline $\begin{array}{l}\mathrm{GaAs}_{0.6} \mathrm{P}_{0.4} \\
\mathrm{GaAs}_{0.35} \mathrm{P}_{0.65} \mathrm{~N} \\
\mathrm{GaAs}_{0.15} \mathrm{P}_{0.85} \mathrm{~N}\end{array}$ & $\begin{array}{l}\text { 赤 } \\
\text { 赤橙 } \\
\text { 黄 }\end{array}$ & $\begin{array}{l}650 \\
630 \\
590\end{array}$ & $\begin{array}{r}70 \\
190 \\
450\end{array}$ & $\begin{array}{l}0.35 \\
1.2 \\
1.1\end{array}$ \\
\hline $\begin{array}{l}\mathrm{GaP}: \mathrm{Zn}, \mathrm{O} \\
\mathrm{GaP}: \mathrm{N} \\
\mathrm{GaP}: \mathrm{N}(\mathrm{LPE})^{*} \\
\left.{ }_{\mathrm{LPE}}{ }^{*} \text { diff }\right)^{*} \\
\mathrm{GaP}\end{array}$ & $\begin{array}{l}\text { 赤 } \\
\text { 黄 } \\
\text { 緑 } \\
\text { 緑 } \\
\text { 純緑 }\end{array}$ & $\begin{array}{l}699 \\
590 \\
565 \\
565 \\
555\end{array}$ & $\begin{array}{r}20 \\
450 \\
610 \\
610 \\
680\end{array}$ & $\begin{aligned} & 3.0 \\
& 0.45 \\
& 4.9 \\
\sim & 0.9 \\
\sim & 0.68\end{aligned}$ \\
\hline GaAlAs & 赤 & 665 & 35 & $\sim 1.0$ \\
\hline
\end{tabular}

よつて変えることが可能である. 現在のところ発光型の フラットパネルの中ではもつとも技術開発が進み，すで に数社のメーカーから製品が売り出されており，世の中 に知られるようになつてきている．しかしその価格はま だ CRT に比べるとかなり高く，カラー化もまだである ので,これに相当するモノクロの CRT に比べるとその 価格は数倍にも達しょう.

プラズマディスプレイを分類すると次のと扬りである.

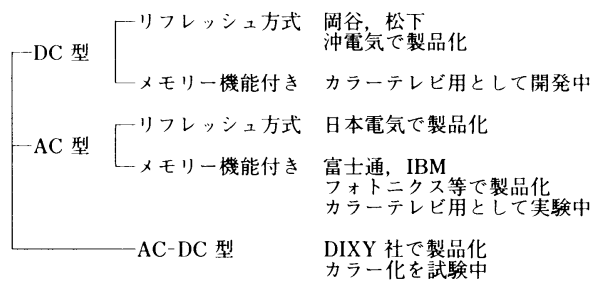

PDP の表示方式は XY ドットマトリックス方式であ るので発光は XY の交点で起こり, CRTのようなちら つきはなく，画面が安定している．ただ，現在市販され ている PDP の大部分がネオンガス発光のオレンジ色で あるため，CRTの青や緑系統の色に慣れた人には最初 抵抗があるかも知れない. PDP は完全にフラットな表 示面であるから画面の端の方まで直線性にすぐれてい る.これは図面などを取り扱う CADにとつては極めて 重要な特性といえるだろう。

最近のパソコンにはすでにプラズマディスプレイが標 準装備できるように専用のインターフェイスが備えられ たものもでてきている.

PDP の駆動方式には開発した会社によつていくつか の方式がある。図 6 には DIXY 社が開発した直流駆動 型の PDP のセル構造が示されてある. 縦方向と横方向 とに互いに直交する多数の棒状の電極があり，電極間に はプラズマ放電が横ににじみでることを防ぐためのバリ アリブが添えてある。また，カソート背面にトリガー電 極が配置され，適切なタイミングでカソード電極に低い 電圧を与えることによりプラズマ放電の開始電圧を低く することができるようになつている．この素子の有効表 
表 6 主要メーカーのプラズマディスプレイモジュールの製品例5)

\begin{tabular}{|c|c|c|c|c|c|}
\hline メーカー名 & 沖電気工業 & ディクシー & 日本電気 & 富士通 & 松下電子 \\
\hline 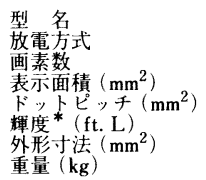 & $\begin{array}{c}\mathrm{SS} 640400 \mathrm{R} \\
\mathrm{DC} \\
640 \times 400 \\
211 \times 132 \\
0.33 \times 0.33 \\
50 \\
280 \times 200 \times 30 \\
1.67\end{array}$ & $\begin{array}{c}\text { D0640SB } \\
\text { DC } \\
640 \times 400 \\
192 \times 120 \\
0.3 \times 0.3 \\
35 \\
276 \times 197 \times 38 \\
1.5\end{array}$ & $\begin{array}{c}\text { PD640G400 } \\
\text { AC リフレンシシュ } \\
640 \times 400 \\
230 \times 144 \\
0.36 \times 0.36 \\
20 \\
289 \times 188 \times 15 \\
1.0\end{array}$ & $\begin{array}{c}\text { FPG0909HFUA } \\
\text { AC } \times モ \text { モ }- \\
152 \times 152 \\
217 \times 217 \\
0.423 \times 0.423 \\
87.6 \\
348 \times 370 \times 194 \\
8.0\end{array}$ & $\begin{array}{c}\text { MD400F } 640 \\
\text { DC } \\
640 \times 400 \\
211 \times 132 \\
0.33 \times 0.33 \\
23.4 \\
200 \times 300 \times 20 \\
1.1\end{array}$ \\
\hline
\end{tabular}

*測定条件は各社で異なる

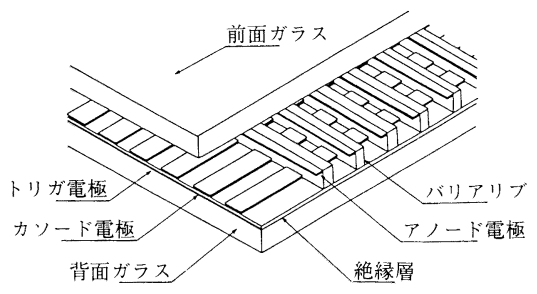

図 6 DIXY 社が開発したプラズマディスプレイパ ネルの断面図

示面積は $192 \times 120 \mathrm{~mm}$ で（ドット数は $640 \times 400 ）$ パ ネルの厚さはわずかに $38 \mathrm{~mm}$ である.

表 6 に現在生産されている各社のプラズマディスプレ イの諸元をまとめて示した.

\section{4. 受光型ディスプレイ}

\section{$4 \cdot 1$ エレクトロクロミック表示素子 $(\mathrm{ECD})^{81 \sim 16)}$}

エレクトロクロミズムとは電気で色が変わるという意 味で，正確には物質に電流を流すと電流の方向によつて その物質の光学吸収の性質が可逆的に変化する現象をい j. J. $R$ PLATT $^{17)} に よ る$ 定義にはもつと広い範囲の現象 まで含められているが，ここでは電気化学的な現象のみ に限定して解説する (図 7 ).

電気化学的現象が起こるためには二つの電極とその間 に存在する電解質の 3 要素によつて構成される. 電流は 一方の電極から電解質に向かつて流れ, もう一方の電極 から外部に出ていく．電流の流れる方向に着目すると， 電極から電解質に向かつて電流が流れ込むところで酸化 が起こり, 電解質から電極に向かつて電流が流れるとこ ろで還元が起こる。 そこで酸化あるいは還元が起こつた とき物質の色が変化すればエレクトロクロミズム現象は 起こり得るわけである.

物質に色が現れるということを物質の電子構造から考 察してみると次のようになる。まず対象となる物質の電 子構造は絶縁体あるいは半導体でなければならない。 のバンドギャップは $1.7 \mathrm{eV}$ 以上であつて可視光線のい ずれかの波長領域に吸収が現れることが必要である. バ ンドギャップが $1.7 \mathrm{eV}$ 以下ではすべての可視光線は吸 収され，黑色となる。このような制限からエレクトロク

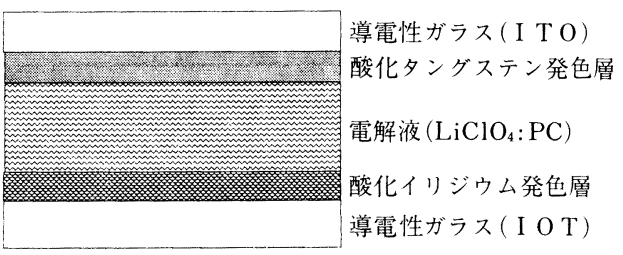

図 7 ECD の基本構造（相補型）

ロミズム現象を示すものの条件はおのずから定まる.

(1)酸化物：バンドギャップが適当な範囲にあるもの というと遷移金属酸化物が挙げられる. 酸化アルミニウ ムのようにバンドギャップが $6 \mathrm{eV}$ 近くもあるものでは この条件を満たさない.一方バンドギャップがたいへん 小さくて，ほとんど電子伝導体に近い銀や水銀の酸化物 では ECの見込みは少ない.

(2)酸化物以外では金属錯体が考えられる．遷移金属 や希土類元素の錯体は中心元素の酸化数が変化すること によつてその吸収スペクトルが大きく変化する.

( 3 )色素あるいは染料に似た構造を持つた有機物で酸 化還元で色が変わるもの, 多くの染料はその合成段階で 酸化あるいは還元反応を経由し, その際色が変化する.

表 7 には現在までに知られている EC 材料とその色 をまとめて示す，金属酸化物が多いが，有機物や有機の 配位子を付けた金属錯体もある．この表の中で発色の項 に酸化発色型とが書いてあるが，酸化発色型とは酸化状 態で色が現れ，還元状態の時にはほとんど無色となるよ うな物質である。還元発色型とはこれと反対に還元状態 で発色し，酸化状態でほとんど無色になるような物質の ことである. 金属酸化物についていえば, 酸化発色型の ものは周期律表で遷移金属の $d$ 電子が半分以上満たさ れているニッケルとかイリジウムによく現れ，還元発色 型は $d$ 電子が半分以下しか満たされていないタングス テンとかニオブのようなものによく現れている.いずれ の場合にも発色状態では混合原子価状態をとることが多 く, その化学構造または電子構造はたいへん複雑なもの が多い

希土類元素を中心にもつジフタロシアニン錯体は印加 電圧によつてその色が数種類も変わるいわゆるマルチカ ラー特性を示すことで注目を浴びている．現在までに希 
表 7 現在までに公表されている ECD 材料 $(\text { 無機材料 })^{8)}$

\begin{tabular}{|c|c|c|c|}
\hline 材 & 色 変 化 & 研 究 発 表 者 & 作 成 法など \\
\hline 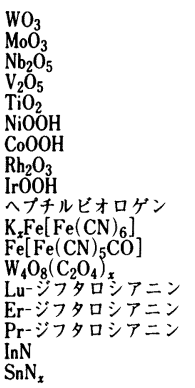 & 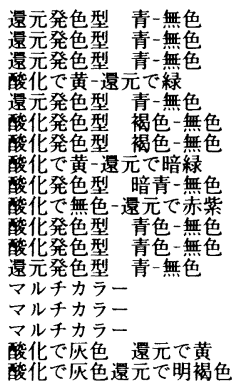 & 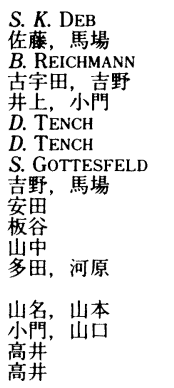 & 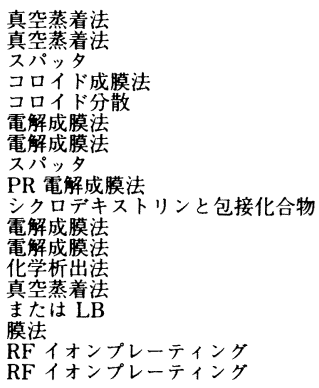 \\
\hline
\end{tabular}

土類元素としてルテシウム, プラセオジム, エルビウム などが報告されている.

ECD の特徵はその発色機構が電気化学的なものであ ること, 自然光を選択吸収して拡散反射するために表示 が自然の色に近く，ディスプレイを長時間見ていても目 の疲れが少ないことなどである，拡散反射であるために 表示を見る方向によつてその見え方が異なることはな い.これを視角依存性がないという。この点が次に述べ る液晶表示素子とは大きく違う点である.

もう一つの特徴はこの ECD には表示内容にメモリー 性があるということである.このメモリー性とはいつた ん表示が現れると, その後は印加電圧を取り除いても表 示内容はそのまま保存され，数日間から数週間にわたつ て維持されることをいう．従つて時計のように毎秒表示 内容を更新するようなディスプレイにはこの ECD は向 かないが, 株価表示とか数日に 1 回の内容更新でよいよ うな揭示板的な用途には向いている. 液晶表示板は大型 のものを作ることは技術的には困難があるが，ECDは その構造上ガラス板の間のピッチの精度があまりうるさ くないので，大型のものが容易に作製できるという利点 がある. しかし欠点も多い. 第 1 に ECD は電気化学反 応であるために，その応答速度は他の表示素子に比べて 遅い. また，化学反応を伴うということは物質が変化す るということなので, 繰返し寿命と信頼性が十分ではな い.

製造コストの面でも液晶表示素子にはかなりの開きがあ つて, 当面同じ目的の市場では勝負にならない.これか らは ECD は大面積化, メモリー性といつた特性を活用 した用途開発になつていくものと思われる．そのような 観点から次のようなものは今後更に開発が進められるも のとなるだろう。

(1)調光ガラス : カーテンの要らない空として ECD を用いた調光ガラス空はたいへん魅力のある分野として 硝子会社では取り組んでいるようである．自動車の空に も用いようとする試みも一部にはなされている.

( 2 )防眩ミラー : 自動車の室内バックミラーやサイド
ミラーには夜間後からヘッドライトを照らされたときま ぶしすぎて困ることがある．このようなときに反射率が 変化するミラーがあると車の付加価值が高くなり, セー ルスポイントの一つになるとされている．この反射率の 変化するミラーに ECD は最適である. 応答速度が遅い ことの方がこの時には有利に働く.

( 3 ) 高圧電線の漏電検知器 : 山中など常時人の巡回監 視が行われにくいところにある高圧電線の絶縁不良はそ の初期には発見が難しいものといわれている. それは雨 の日とか湿度の高いときのみ現れるからである。この漏 電検知に ECD のメモリー性を利用して漏電箇所を記録 し, 早期発見する試みが凸版印刷(株)中央研究所と四国 電力(株)との共同開発で行われてきている. 今後の成果 が期待される.

\section{$4 \cdot 2$ 液晶表示素子 (LCD) ${ }^{18) \sim 20)}$}

非発光型のディスプレイの中でもつとも一般的なもの は液晶表示素子である. 液晶材料の開発も進み以前に比 べると表示のコントラストはかなりよくなつた. 通常は $\mathrm{TN}$ 型の表示方式を使つている（図 8 ). TN 方式とは Twisted Nematic 型という意味で片方のガラス面からも う一方のガラス面に向かつて $90^{\circ}$ ねじれた形となつてお

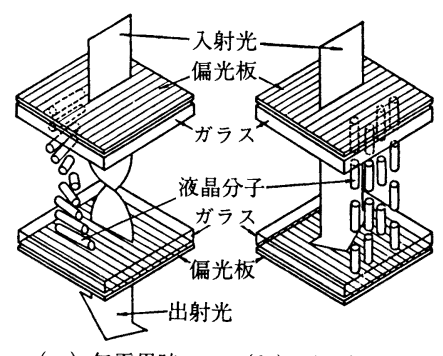

(a) 無電界時

(b) 電圧印加時

TN 方式の LCD (a) 無電解時は, 旋光性を有し, (b) 電圧印加時 には旋光性が失われる。.上下の偏光板は $90^{\circ}$ 交差しており電界に より入射光の透過を制御し，コントラストを生じさせる.

図 8 TN 型液晶ディスプレイの原理 ${ }^{20)}$ 
り，電場が印加されるとそのねじれが解けてすべての液 晶分子が電場の方向に整列するようになる。 あらかじめ $90^{\circ}$ に交差するように両面のガラスの上に偏光板を設け ておくと, 電場がかかつていないところの液晶分子は $90^{\circ}$ にねじれながら整列しているので偏光の光は透過し 明るく見える. 電場がかかつたところの液晶分子はねじ れた形に整列していないので偏光された光はこれを透過 することができず暗く見える．この原理を利用して表示 を行う。ここで液晶を最初にガラス面に整列させるには 特殊な表面処理が必要になる。通常はラッピングという 工程でガラス表面を刷毛のようなもので一定方向にブ ラッシングし，ガラス表面に吸着する液晶の第一層の配 列方向を決める。最近では液晶のねじれの角度を $90^{\circ} よ$

\section{表 8 代表的な強誘電性液晶の分子構造}

$\mathrm{C}_{n} \mathrm{H}_{2 n+1} \mathrm{O}-\mathrm{CH}=\mathrm{N}-\mathrm{CO} \cdot \mathrm{OCH}_{2} \mathrm{C}^{*} \mathrm{H}\left(\mathrm{CH}_{3}\right) \mathrm{C}_{2} \mathrm{H}_{5}(n=7,8,10)$ $\mathrm{C}_{n} \mathrm{H}_{2 n+1}-\mathrm{N}=\mathrm{CH}-\mathrm{O}\left(\mathrm{CH}_{2}\right)_{5} \mathrm{C}^{*} \mathrm{H}\left(\mathrm{CH}_{3}\right)_{2} \mathrm{H}_{5} \quad(n=4,8,12)$ $\mathrm{C}_{2} \mathrm{H}_{5} \mathrm{C}^{*} \mathrm{H}\left(\mathrm{CH}_{3}\right)\left(\mathrm{CH}_{2}\right)_{m} \mathrm{O}-\mathrm{O}-\mathrm{N}=\mathrm{N}-\mathrm{O}-\mathrm{O}\left(\mathrm{CH}_{2}\right)_{m} \mathrm{CH}_{3} \mathrm{C}^{*} \mathrm{H}\left(\mathrm{CH}_{3}\right)_{2} \mathrm{C}_{5}(m=4,5)$ $\mathrm{C}_{n} \mathrm{H}_{2 n+1} \mathrm{O}-\bigcirc-\mathrm{CO} \cdot \mathrm{OCH}_{2} \mathrm{C}^{*} \mathrm{H}\left(\mathrm{CH}_{3}\right) \mathrm{C}_{2} \mathrm{H}_{5} \quad(\boldsymbol{n}=5,7,8,10)$ $\mathrm{C}_{n} \mathrm{H}_{2 n+1} \mathrm{O}-\mathrm{CO} \cdot \mathrm{O}-\mathrm{CO} \cdot \mathrm{OCH}_{2} \mathrm{C}^{*} \mathrm{H}\left(\mathrm{CH}_{3}\right) \mathrm{C}_{2} \mathrm{H}_{5} \quad(n=7 \sim 10,12,14,16)$ $\mathrm{C}_{n} \mathrm{H}_{2 n+1} \mathrm{O}-\mathrm{CO} \cdot \mathrm{O}-\mathrm{O} \mathrm{CH}_{2} \mathrm{C}^{*} \mathrm{H}\left(\mathrm{CH}_{3}\right) \mathrm{C}_{2} \mathrm{H}_{5} \quad(n=9,10)$

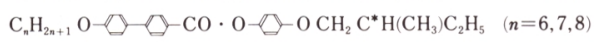
$\mathrm{C}_{n} \mathrm{H}_{2 n+1}-\mathrm{N}-\mathrm{O} \cdot\left(\mathrm{CH}_{2}\right)_{3} \mathrm{C}^{*} \mathrm{H}\left(\mathrm{CH}_{3}\right)_{2} \mathrm{H}_{5} \quad(n=8 \sim 12)$ $\mathrm{C}_{8} \mathrm{H}_{17} \mathrm{O}-\mathrm{N}-\mathrm{O} \mathrm{CH}_{2} \mathrm{C}^{*} \mathrm{H}\left(\mathrm{CH}_{3}\right) \mathrm{OC}_{n} \mathrm{H}_{2 n+1} \quad(n=1,2,3)$ $\mathrm{C}_{n} \mathrm{H}_{2 n+1} \mathrm{O} Q-\mathrm{OCH}-\mathrm{CO} \cdot \mathrm{OC}^{*} \mathrm{H}\left(\mathrm{CH}_{3}\right) \mathrm{C}_{3} \mathrm{H}_{7} \quad(n=8,9,10)$
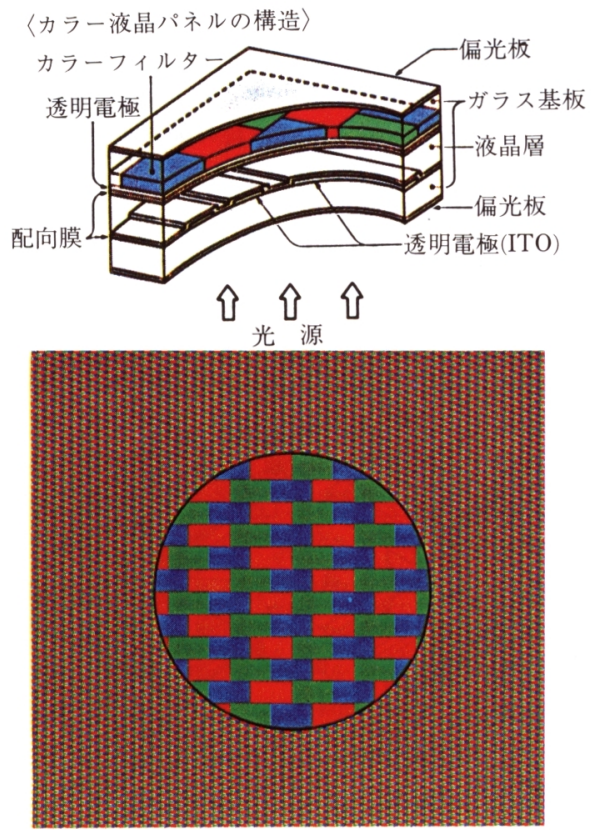

図 9 液晶用カラーフィルターの構造 （上）断面（下）フィルターの拡大図
り大きくし $370^{\circ}$ に及ぶ回転角を与える方式も出てきて いる.

液晶表示方式には TN 型のほかにゲストーホスト型 ( $\mathrm{GH}$ 型）というものもある.コントラストが良くない のであまり用いられていない.

液晶自体については種々のものが開発され, 最近では 強誘電性液晶というのが話題になつてきている。これは 応答速度が格段に速く, コントラストもすぐれているも のである．強誘電性液晶とは液晶分子自体に恒久的な電 気分極（永久双極子）が存在するので電場に対する応答 が速いのである．表 8 にはいくつかの代表的な強誘電性 液晶を示した。

一方液晶の駆動方法についても画素の一個一個に IC を対応させて液晶に On-Off を与える電圧を制御する Active Matrix 方式というのが出てきている.この方式 のものは画面のコントラストが改善され見やすくなつて いる．しかし液晶の画素の数だけ IC が必要になるので かなりのコスト高になる. そこでもうすこし安い材料で IC の代わるような駆動方法も研究されている. その一 つの可能性として非直線性の V-I 特性を持つた抵抗素 子 MIM とか MOS 構造の接合素子が挙げられる.

液晶表示素子のカラー化はもう一つの大きな要望であ る. 液晶自体は原理的に明暗, あるいは白黒の表示しか できないので，カラー化するためには RGB三原色の フィルターを用いる. 通常でも小さな液晶の画素の一つ 一つを更に 3 原色のフィルターに分けることはフォト エッチング技術や印刷などの微細加工技術が必要であ る.

図 9 は日本写真印刷(株)提供のカラーフィルターの拡 大図で, 1 こまの実際の大きさはわずかに $0.1 \mathrm{~mm}$ の オーダーである。 ちなみに現在多用されている高密度力 ラー CRT のドットサイズは $0.3 \mathrm{~mm}$ であるからこの フィルターの細かさがいかに小さいかが分かるだろう. このカラーフィルターはフォトリソグラフィー技術によ つて作られるのであるが，この RGB を色度図上に表す と図 10 のようになつている.

液晶表示板のもつとも大きな欠点は見る角度によつて はたいへん見にくくなることで，これを視覚依存性があ るという．ガラス表面は $4 \%$ 程度の表面正反射があつ て表裏 2 枚のガラスを合わせるとかなりの割合になる. この表面正反射をいかに低減するかということも大きな 課題となつている．表面反射率を小さくする，あるいは 全くゼロにすることは多層構造の薄膜を付けることによ つてある程度可能であることが計算されている，我々が 使用している眼鏡の表面にも正反射を抑えるコーティン グがなされているものがあることはよく知られている. 通常は低い屈折率をもつ $\mathrm{MgF}_{2}$ の薄膜を蒸着する方法 がとられているが, 大面積を処理するには不適当である. そこでこれに代わつてガラスの表面をふつ化水素酸で 
表 9 各種平面表示材料の比較

\begin{tabular}{|c|c|c|c|c|c|c|}
\hline & 表示素子 & 表示原理 & 大面積化 & 高密度化 & カラー化 & 問題点 \\
\hline 受 光 型 & $\begin{array}{l}\text { 液晶 } \\
\text { エ上トロクロミック } \\
\text { 電気泳動型 }\end{array}$ & 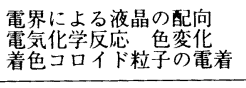 & $\begin{array}{l}\text { 不適 } \\
\text { 可 } \\
\text { 可 } \\
\end{array}$ & 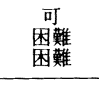 & $\begin{array}{l}\text { 可 } \\
\text { 困難 } \\
\text { 困難 } \\
\end{array}$ & $\begin{array}{l}\text { 梘角依在 } \\
\text { 愈 } \\
\text { 安定性 }\end{array}$ \\
\hline 発 光 型 & $\begin{array}{l}\text { エレクトロルミネッセンス } \\
\text { プラズ } \\
\text { 霔光表示板 } \\
\text { 平光板型 CRT }\end{array}$ & 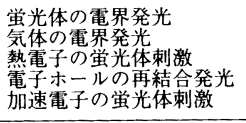 & $\begin{array}{l}\text { やp可 } \\
\text { 可 } \\
\text { 不適 } \\
\text { 不適 } \\
\text { 不適 }\end{array}$ & $\begin{array}{l}\text { 可 } \\
\text { 可 } \\
\text { 否適 } \\
\text { 否適 } \\
\text { 不適 }\end{array}$ & $\begin{array}{l}\text { や可 } \\
\text { や可 } \\
\text { 可 } \\
\text { 困難 } \\
\text { 可 }\end{array}$ & $\begin{array}{l}\text { 高電压 } \\
\text { 高電厔 } \\
\text { 価積华 } \\
\text { 構造複雑 }\end{array}$ \\
\hline & 参考 CRT & 加速電子の蛍光体刺激 & 可 & 可 & 可 & 大容積 \\
\hline
\end{tabular}

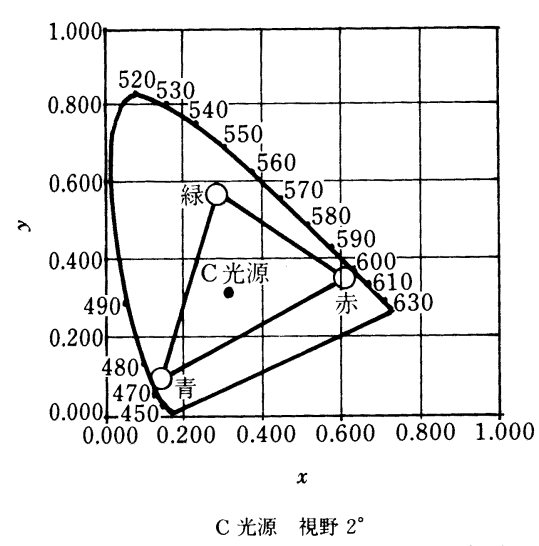

図 10 液晶用カラーフィルターの色度図

エッチングしてガラス表面を約 $1000 \AA$ 程度ポーラスに して反射率を低減する方法がある。この時ポーラス層の 孔の大きさは光の波長より小さいので, ポーラス層はガ ラスと空気の中間に当たる平均の屈折率をもつた透明体 として挙動する．これは低屈折率の層をコーティングし たと同様な効果である. ふつ化水素酸の代わりにけいふ つ化水素酸を用いると更に良い結果が得られたとの報告 がある.

液晶の動作に悪影響を及ぼす成分の一つにガラス内部 から溶け出してくるナトリウムイオンがある.これを防 止するためにガラスの表面に $\mathrm{SiO}_{2}$ の薄膜を作ることも 行われている.

\section{$4 \cdot 3$ 電気泳動型表示素子 $(\text { EPID })^{21 / 221}$}

この表示素子はまだ研究段階にあるもので，製品とし て出回つているものではないが，今後の動きが注目され る表示方式である．その動作原理は次のとおりである.

適当な分散媒の中にコロイド粒子を懸濁した状態にして 2 枚の導電性ガラス（ITO）の間に挟み，これに直流電 場を加えるとコロイド粒子は電荷を帯びているのでどち らかの電極方向へ泳動し付着する.ここでコロイド粒子 に色をつけておくとコロイド粒子が電着したところに表 示が現れる.コロイド粒子の移動は界面導電現象による もので,これにはコロイド粒子のり電位が重要である. コロイド粒子として白色の酸化チタンコロイドが用いら
れるが, 酸化チタンの比重は 4.2 とやや大きいので, 水の中では重力の力で沈降しやすい. そこで長期間安定 にコロイド状態を保つためにはコロイドの凝集を防ぐよ うな界面活性剤を選ぶ必要がある。理想的にはコロイド 粒子の比重と分散媒の比重とをできるだけ近接させて重 力による沈降を防止することが一番である．そのために は溶媒の比重を上げるか, コロイド粒子の比重を水の比 重の近づけるかいずれかである. 溶媒の比重を上げるこ とは現実的ではないので，コロイドにできるだけ比重の 軽い物質を選ぶことになろう。

EPID で表示される色調は ECD と同じく自然光の拡 散反射であるので，目には優しく理想的なディスプレイ システムと思われる。，一度電極に付着したコロイド粒子 はVan der Waales 力でそのまま留まるので ECD と同 じくメモリー機能を有する.

\section{5.おわりに}

以上現在製造市販されている，あるいは開発研究の途 中にある表示材料を表示方式別に分けて解説した。これ ら現時点での実用性の比較をすると表 9 のようになる. 今後どの夕イプの表示方式が主流になるかということは 即断できないが，世の中のニーズの多様化と，新しい周 辺機器の開発および労㗢環境衛生上の観点から，また古 産性と価格の均衡からおのずから選択されて決まつてい くものと思われる.

\section{文献}

1 ) 中西洋一郎: 電子材料表面処理技術部会講演テキスト (金属表面技術協会編) (1987 年 5 月)

2 ) 过山文治郎: 電子材料表面処理技術部会講演テキスト （金属表面技術協会編）（1987 年 5 月）

3 ) 関戸睦弘: 表示材料表面技術 (1987), p. 159 [リアライズ 社]

4 ) 機能材料 [上] (本間基文, 北田正弘編) (1981), p. 123 [アグネ社]

5 ) 村上 宏: 表示材料表面技術 (1987), p. 173 [リアライズ 社]

6 ）村上 宏: 電子材料表面処理技術部会講演テキス卜（金属 表面技術協会編) (1986 年 4 月)

7 ) 関川忠彦: 電子材料表面処理技術部会講演テキス卜（金属 表面技術協会編）(1986 年 4 月）

8 ）馬場宣良, 渡辺誠一: 金属表面技術, 35 (1984), p. 498

9 ) 佐藤 進, 清野陽介: 電子通信学会論文誌, 165 (1982), 
p. 629

10) 井上英一, 小門 宏, 伊沢 晃: 応用物理, 43 (1974), p. 1

11) B. Reichmann and A. J. Bard: J. Electrochem. Soc., 127 (1980), p. 241

12) S. Gottesfeld and J. P. E. MacIntyre: J. Electrochem. Soc., 126 (1979), p. 1077

13) Y. Sato, $K$. Ono, $T$. Kobayashi, $H$. Wakabayashi and $H$. YAMANAKA: J. Electrochem. Soc., 134 (1987), p. 570

14）多田弘明, 藤野耕三, 河原秀夫: NSG Technical Report No. 3 (1986), p. 9

15）山名昌男: 応用物理, 48 (1979), p. 411
16) O. TAKaI: Proc. 6 th Int. Display Research Conf. (Japan Display'86) (1986), p. 364

17) J. R. Platt: J. Chem. Phys., 34 (1961), p. 862

18）苗村省平: 表示材料表面技術（1987)，p. 21 [リアライズ 社]

19）宮沢 要: 電子材料表面処理技術部会講演テキス卜（金属 表現技術協会編）(1984 年 11月）

20）両角伸治: 日本の科学と技術，9-10 (1984), p. 52

21）馬場宣良: 電気化学, 54 (1986), p. 99

22）馬場宣良, 本間英夫, 逢坂啓彌, 小山昇共著: 電子材料 (1986), p. 73[講談社サイエンティフィク] 